\title{
Complement and its role in innate and adaptive immune responses
}

\author{
Jason R Dunkelberger ${ }^{1}$, Wen-Chao Song ${ }^{1}$ \\ ${ }^{I}$ Institute for Translational Medicine and Therapeutics and Department of Pharmacology, University of Pennsylvania School of \\ Medicine, 1254 BRB II/III, 421 Curie Blvd, Philadelphia, PA, 19104, USA
}

The complement system plays a crucial role in the innate defense against common pathogens. Activation of complement leads to robust and efficient proteolytic cascades, which terminate in opsonization and lysis of the pathogen as well as in the generation of the classical inflammatory response through the production of potent proinflammatory molecules. More recently, however, the role of complement in the immune response has been expanded due to observations that link complement activation to adaptive immune responses. It is now appreciated that complement is a functional bridge between innate and adaptive immune responses that allows an integrated host defense to pathogenic challenges. As such, a study of its functions allows insight into the molecular underpinnings of host-pathogen interactions as well as the organization and orchestration of the host immune response. This review attempts to summarize the roles that complement plays in both innate and adaptive immune responses and the consequences of these interactions on host defense.

Keywords: complement, innate immunity, adaptive immunity, inflammation, host defense

Cell Research (2010) 20:34-50. doi: 10.1038/cr.2009.139; published online 15 December 2009

\section{Introduction}

The mammalian immune system is a remarkable complex of biochemical processes enabling efficient detection and prosecution of pathogens that threaten host viability. The incredible complexity of mammalian immune systems is required to provide adequate defense in spite of the impressive number of pathogens and host processes that cause disease. Immune processes have traditionally been divided into two broad, but interconnected, subsystems on the basis of their functions in host defense. The adaptive immune system is organized around two classes of specialized lymphocytes, T and B cells, which display an extremely diverse repertoire of antigen-specific recognition receptors that enable specific identification and elimination of pathogens, as well as adaptive immune measures that ensure tailored immune responses, as well as long-lived immunological memory against reinfection. In contrast, the innate arm of immu-

Correspondence: Wen-Chao Song

Tel: +215-573-6641; Fax: +215-746-8941

E-mail: Songwe@upenn.edu nity is composed of those immunological effectors that provide robust, immediate, and nonspecific immune responses. These include evolutionarily primitive humoral, cellular, and mechanical processes that nevertheless play a vital role in the protection of the host from pathogenic challenge.

The complement system comprises a far-reaching and vital component of innate immunity and represents one of the major effector mechanisms of the innate immune system. Discovered in 1896 by Bordet as a heat-labile component of serum, it was so named for its ability to 'complement' the antibacterial properties of antibody in the heat-stabile fraction of serum. It is now appreciated that complement is a complex network of plasma and membrane-associated serum proteins which can elicit highly efficient and tightly regulated inflammatory and cytolytic immune responses to infectious organisms (bacteria, viruses, parasites), tissue damaged by physical, chemical, or neoplastic insults, and other surfaces identified as 'nonself'.

For many years after its discovery, the role of complement in immunity was thought to be confined to innate immune responses with no impact on adaptive immune responses, in much the same way as innate immunity, in 
general, was relegated to those functions of immunity that involved prevention and confinement of infection while adaptive immunity provided effectors required to clear the infection. The ability to separate the functions of the two arms of immunity was called into question as early as the 1970s, and since then the body of knowledge illustrating the interplay between the adaptive and innate wings of immunity has grown dramatically. Similarly, the ability of complement to not only affect robust innate immune responses but also to interface with and influence T- and B-cell biology and adaptive responses has become increasingly appreciated. This review attempts to summarize the roles that complement biology plays in the immune response, both in the innate detection and elimination of pathogenic infections and in the modulation of adaptive immune responses.

\section{Complement origins and activation}

Complement is a system of more than 30 proteins in the plasma and on cell surfaces, amounting to more than $3 \mathrm{~g} / \mathrm{L}$ and constituting more than $15 \%$ of the globular fraction of plasma [1]. This array of proteins is organized into a hierarchy of proteolytic cascades that start with the identification of pathogenic surfaces and lead to the generation of potent proinflammatory mediators (anaphylatoxins), opsonization ('coating') of the pathogenic surface through various complement opsonins (e.g., C3b), and targeted lysis of the pathogenic surface through the assembly of membrane-penetrating pores known as the membrane attack complex (MAC) [2, 3]. Complement represents an evolutionarily ancient component of host defense, and the evolutionary survival value of complement serves to accentuate the important roles it plays in host defense. Originally, it was thought to be a unique vertebrate feature, showing high degrees of homology in structure and function among the higher vertebrates as phylogentically ancient as the nurse shark [4]. However, genomic and functional studies on complement effector molecules have discovered complement analogs in even more ancient phyla, including Cephalochordata (lancelets), Urochordata (tunicates), and Echinodermata (sea urchins) [5-7]. More recently, functional C3 was identified in horseshoe crab (Carcinoscorpius rotundicauda) and cnidarian anthrozoans (Nematostella vectensis [starlet sea anemone]), demonstrating that the complement system is ancient $[8,9]$. Adaptive immunity is, by contrast, much younger and is generally considered restricted to jawed vertebrates [10]. Furthermore, adaptive immune processes are rooted in the earlier innate immune processes, providing logical evidence for why complement (and innate immunity in general) would integrate with mechanisms of the adaptive immune response to infection.

The complement system can be activated through three major pathways: classical, lectin, and alternative (Figure 1) $[1,2,11]$. Initiation of the classical pathway occurs when $\mathrm{C} 1 \mathrm{q}$, in complex with $\mathrm{C} 1 \mathrm{r}$ and $\mathrm{C} 1 \mathrm{~s}$ serine proteases (the $\mathrm{C} 1$ complex), binds to the $\mathrm{Fc}$ region of complementfixing antibodies (generally $\operatorname{IgG}_{1}$ and $\operatorname{IgM}$ ) attached to pathogenic surfaces. Autocatalytic activation of $\mathrm{C} 1 \mathrm{r}$ and $\mathrm{C} 1 \mathrm{~s}$ in turn cleaves $\mathrm{C} 4$ and $\mathrm{C} 2$ into larger $(\mathrm{C} 4 \mathrm{~b}, \mathrm{C} 2 \mathrm{a})$ and smaller $(\mathrm{C} 4 \mathrm{a}, \mathrm{C} 2 \mathrm{~b})$ fragments. The larger fragments associate to form $\mathrm{C} 4 \mathrm{bC} 2 \mathrm{a}$ on pathogenic surfaces, and the complex gains the ability to cleave $\mathrm{C} 3$ and is termed the $\mathrm{C} 3$ convertase. Generation of the $\mathrm{C} 3$ convertase, which cleaves $\mathrm{C} 3$ into the anaphylatoxin $\mathrm{C} 3 \mathrm{a}$ and the opsonin $\mathrm{C} 3 \mathrm{~b}$, is the point at which all complement activation cascades converge [2]. When $\mathrm{C} 3$ is cleaved into $\mathrm{C} 3 \mathrm{~b}$, it exposes an internal thioester bond that allows stable covalent binding of $\mathrm{C} 3 \mathrm{~b}$ to hydroxyl groups on proximate carbohydrates and proteins. This activity underpins the entire complement system by effectively 'tagging' microorganisms as foreign, leading to further complement activation on and around the opsonized surface and terminating in the production of anaphylatoxins and assembly of the MAC $[1,11]$.

The lectin pathway functions in an analogous, but immunoglobulin-independent, fashion. As opposed to recognizing antigen-antibody immune complexes, the lectin pathway employs germline-encoded patternrecognition receptors (PRRs), such as mannose-binding lectin (MBL) and ficolins, to conduct nonself recognition [2]. Antigen-recognition receptors (e.g., antibody, T-cell receptors) of the adaptive immune system hypothetically have the ability to recognize every possible antigen by way of their incredible somatic diversity. PRRs, in contrast, focus on a few highly conserved structures present in large groups of microorganisms popularly referred to as pathogen-associated molecular patterns (PAMPs) [12]. Examples of PAMPs include endotoxin or lipopolysaccharide of Gram-negative bacteria, lipoteichoic acid of Gram-positive bacteria, and $\beta$-glucan of fungi $[13,14]$. $\mathrm{MBL}$ is a well-characterized receptor of the collectin family, so termed because of the fusion of a collagenous domain to a calcium-dependant lectin domain, which are synthesized in the liver and secreted into the plasma as a component of the acute-phase response $[12,13]$. MBL can bind to common carbohydrate PAMPs on Grampositive and Gram-negative bacteria and yeast, as well as on some viruses and parasites $[15,16]$. Similar to the $\mathrm{C} 1$ complex of the classical pathway, MBL is complexed with MBL-associated serine proteases (MASPs)-1, -2 , and -3 which are functionally and structurally similar 


\section{CLASSICAL PATHWAY}

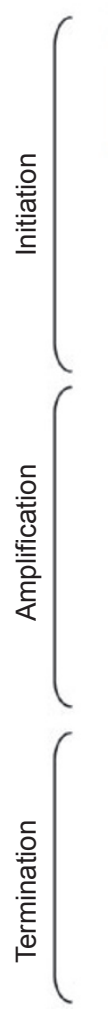

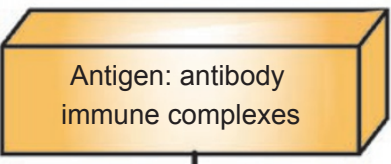

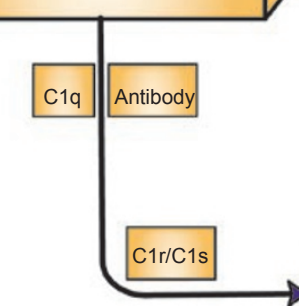

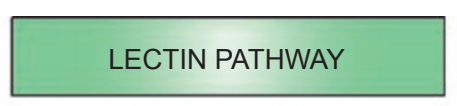

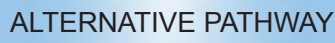

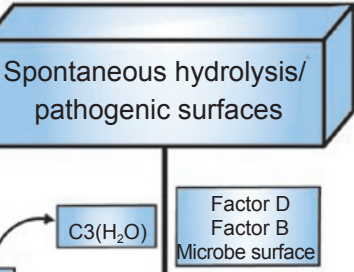

PAMP recognition by lectins

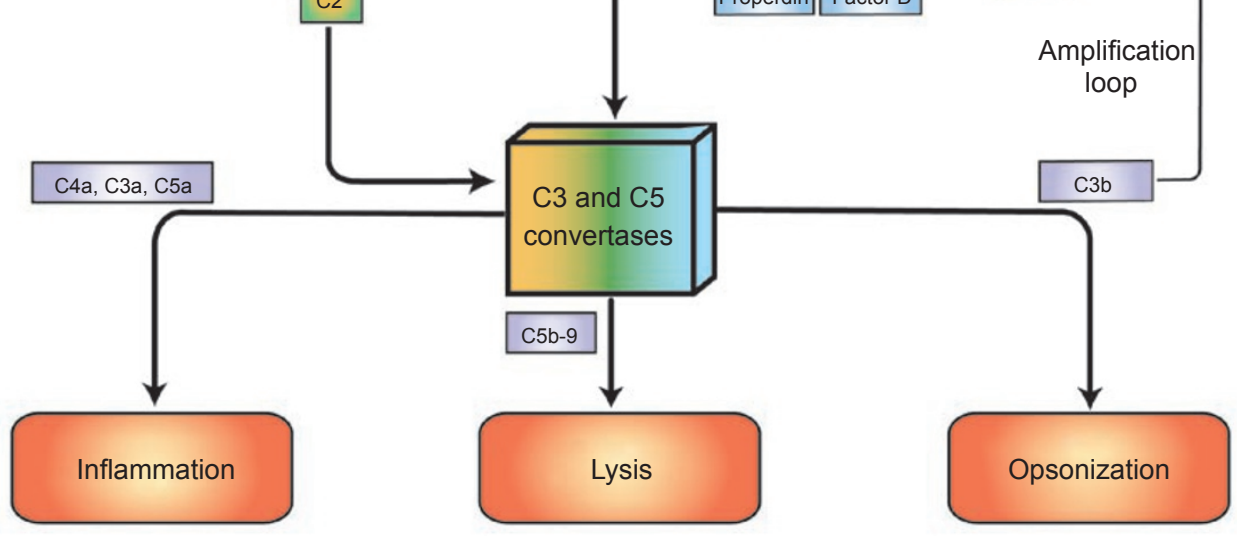

Figure 1 The complement pathway. Complement can be activated through three pathways: classical, lectin, and alternative. The classical pathway is activated when $\mathrm{C} 1 \mathrm{q}$ binds to antibody attached to antigen, activating $\mathrm{C} 1 \mathrm{r}$ and $\mathrm{C} 1 \mathrm{~s}$, which cleave $\mathrm{C} 4$ and C2. The lectin pathway is activated when mannose-binding lectin (MBL) encounters conserved pathogenic carbohydrate motifs, activating the MBL-associated serine proteases (MASPs) and again cleaving C4 and C2. C4 and C2 cleavage products form the classical and lectin pathway C3 convertase, $\mathrm{C} 4 \mathrm{bC} 2 \mathrm{a}$, which cleaves $\mathrm{C} 3$ into $\mathrm{C} 3 \mathrm{~b}$ and $\mathrm{C} 3 \mathrm{a}$. A second molecule of $\mathrm{C} 3 \mathrm{~b}$ can associate with $\mathrm{C} 4 \mathrm{bC} 2 \mathrm{a}$ to form the $\mathrm{C} 5$ convertase of the classical and lectin pathways, $\mathrm{C} 4 \mathrm{bC2} \mathrm{aC} 3 \mathrm{~b}$. The alternative pathway (AP) is activated when $\mathrm{C} 3$ undergoes spontaneous hydrolysis and forms the initial $A P C 3$ convertase, $C 3\left(\mathrm{H}_{2} \mathrm{O}\right)$ $\mathrm{Bb}$, in the presence of Factors $\mathrm{B}$ and $\mathrm{D}$, leading to additional $\mathrm{C} 3$ cleavage and eventual formation of the AP C3 convertase $(\mathrm{C} 3 \mathrm{bBb})$ and AP $\mathrm{C} 5$ convertase $(\mathrm{C} 3 \mathrm{bBbC} 3 \mathrm{~b})$. Properdin facilitates AP activation by stabilizing AP convertases. All three pathways culminate in the formation of the convertases, which in turn generate the major effectors of the complement system: anaphylatoxins ( $\mathrm{C} 4 \mathrm{a} / \mathrm{C} 3 \mathrm{a} / \mathrm{C} 5 \mathrm{a})$, the membrane attack complex (MAC), and opsonins (e.g., C3b). Anaphylatoxins are potent proinflammatory molecules derived from the cleavage of $\mathrm{C} 4, \mathrm{C} 3$, and $\mathrm{C} 5$. The MAC is a terminal assembly of complement components C5b through C9, which can directly lyse targeted surfaces. C3b induces phagocytosis of opsonized targets and also serves to amplify complement activation through the AP.

(although not identical, see Harmat et al. [17]; Bally et al. [18]; Gal et al. [19]) to C1s and C1r, such that the binding of MBL to pathogenic surfaces leads to the activation of associated MASPs, cleavage of $\mathrm{C} 2$ and $\mathrm{C} 4$, and ultimately to the generation of the $\mathrm{C} 3$ convertase of both classical and lectin pathways, C4bC2a [12, 13, 17-23].

The AP is mechanistically distinct from the classical and lectin pathways (Figure 1). It is initiated by the low-level, spontaneous hydrolysis of $\mathrm{C} 3$ (which is very abundant in the plasma) to the $\mathrm{C} 3 \mathrm{~b}$ analog, $\mathrm{C} 3\left(\mathrm{H}_{2} \mathrm{O}\right)$ (which also contains an activated thioester bond), which will bind to Factor B in turn allowing cleavage of Factor $\mathrm{B}$ into $\mathrm{Bb}$ and $\mathrm{Ba}$ by Factor $\mathrm{D}$ and forming the initial AP C3 convertase, $\mathrm{C} 3\left(\mathrm{H}_{2} \mathrm{O}\right) \mathrm{Bb}$ [2]. This $\mathrm{C} 3$ convertase forms the basis of an amplification loop in which $\mathrm{C} 3\left(\mathrm{H}_{2} \mathrm{O}\right) \mathrm{Bb}$ starts to convert $\mathrm{C} 3$ into $\mathrm{C} 3 \mathrm{~b}$ and $\mathrm{C} 3 \mathrm{a}$, in an analogous fashion to the $\mathrm{C} 3$ convertase $(\mathrm{C} 4 \mathrm{bC} 2 \mathrm{a})$ of the classical and lectin pathways. $\mathrm{C} 3 \mathrm{~b}$ generated in such a fashion can bind to surfaces in the vicinity and associate with Factor B, which can in turn be activated by Factor 
$\mathrm{D}$ to form $\mathrm{C} 3 \mathrm{bBb}$, the predominant $\mathrm{AP} \mathrm{C} 3$ convertase $[1$, 11]. This complex can be further stabilized by properdin (Factor P), which helps to amplify AP activation [24]. As a consequence of this constitutive activation, and due to the ability to form a feedback amplification pathway, there are a number of complement inhibitory proteins responsible for confining complement activation to appropriate contexts to prevent errant complement activation in the healthy host, which will be discussed below.

Further insight into the formation of $\mathrm{C} 3$ convertases of all three pathways has been afforded through structural determinations of key C3 convertase components. Due to the size of $\mathrm{C} 3$, determination of its complete structure remained elusive for many years. Solving the structures of the smaller cleavage products of $\mathrm{C} 3$, including $\mathrm{C} 3 \mathrm{a}$ and $\mathrm{C} 3 \mathrm{~d}$ (discussed below), eventually culminated in the structural determination of intact $\mathrm{C} 3$ which afforded extensive insight into C3's activation, regulation, and biological functions [25-27]. Insight into the arrangement and activation of the AP C3 convertase has recently been gained as a result of the structural determinations of both Factor B and the AP proconvertase, C3bB [28, 29]. Similarly, the catalytic function of the classical pathway $\mathrm{C} 3$ and $\mathrm{C} 5$ convertases has been illuminated through the structural determination of $\mathrm{C} 2 \mathrm{a}$, allowing insight into the architecture and biological activities of this pathway [30].

Two additional mechanisms for the initiation of complement activation have recently been described, which introduce novel models for complement activation with currently undefined physiological roles. The first mechanism involves properdin, which has a canonical role in AP activation by stabilizing the AP $\mathrm{C} 3$ convertase $\mathrm{C} 3 \mathrm{bBb}$. However, additional evidence has demonstrated that properdin could promote de novo $\mathrm{C} 3$ convertase assembly when immobilized to an inert surface and initiate C3 convertase formation on microbial surfaces (such as Neisseria gonorrhoeae) [31,32]. The novel role of properdin in AP complement initiation was supported by evidence from a properdin knockout mouse model [33]. Additionally, it has been reported that $\mathrm{C} 3$ and $\mathrm{C} 5$ can be directly cleaved by proteases unrelated to the complement cascade, such as kallikrein and thrombin (which are involved in coagulation), leading to an additional source of anaphylatoxins (C5a and C3a) and establishing a novel and potentially important connection between the complement and coagulation cascades $[34,35]$.

\section{Regulation of complement activation}

Due to the destructive potential of complement activation, especially in light of the potent feedback amplification ability of the AP, complement activities need to be confined to appropriate pathogenic surfaces, and generation of potent effectors needs to be tightly regulated to prevent collateral damage to healthy host tissues. Therefore, many steps involved in complement activation are checked by inhibitors so that the final system represents an intricate, homeostatic balance between the efficient detection and destruction of pathogens and the minimization of bystander tissue damage. Complement regulation occurs predominantly at two steps within the cascades, at the level of the convertases, both in their assembly and in their enzymatic activity, and during assembly of the MAC (Figure 2) [36]. Upon generation of $\mathrm{C} 4 \mathrm{~b}$ and $\mathrm{C} 3 \mathrm{~b}$ fragments (through upstream complement activation) and their covalent linkage to cellular surfaces, they experience one of the two fates. The first, which prevents these molecules from forming active convertases, is the catabolism of $\mathrm{C} 3 \mathrm{~b}$ and $\mathrm{C} 4 \mathrm{~b}$ via the constitutively active serine protease Factor I which can cleave $\mathrm{C} 3 \mathrm{~b}$ and $\mathrm{C} 4 \mathrm{~b}$ into inactive fragments, such as $\mathrm{iC} 3 \mathrm{~b}, \mathrm{C} 3 \mathrm{c}$, and $\mathrm{C} 3 \mathrm{dg}$ (Figure 2A) [37]. To prevent nonspecific C3b degradation, for instance in the case of proper complement activation, Factor I requires cofactors for its proteolytic activity. These cofactors include membrane cofactor protein (MCP; CD46), complement receptor 1 (CR1), and Factor $\mathrm{H}$ which are either intrinsic membrane proteins on host cells or have various mechanisms to ensure preferential cofactor activity on host surfaces, and thereby limit complement activation in these contexts and prevent bystander tissue damage [38-40].

The second potential fate for deposited $\mathrm{C} 3 \mathrm{~b} / \mathrm{C} 4 \mathrm{~b}$ fragments is to form active convertases, consistent with their normal biological imperative. To prevent unregulated C3 convertase formation in the event that $\mathrm{C} 3 \mathrm{~b}$ deposition cannot be controlled, there are several complement inhibitors that possess inhibitory and/or decay-accelerating activity for convertases. A primary example of this category of complement inhibitors is decay-accelerating factor (DAF; CD55), which serves to inhibit assembly of new $\mathrm{C} 3$ convertases and shorten the half-life of preformed convertases, thereby limiting their ability to participate in further complement activation $[36,38]$. Other complement inhibitors with decay-accelerating activity include CR1, Factor $\mathrm{H}, \mathrm{C} 4$-binding protein (C4BP), and the rodent-specific regulator Crry (Figure 2B) [38]. New structural advances have helped to elucidate the mechanistic basis of convertase regulation. A recent study has solved the structure of the first four domains of Factor $\mathrm{H}$ in complex with $\mathrm{C} 3 \mathrm{~b}$, suggesting that Factor $\mathrm{H}$ destabilizes the AP C3 convertase through competition and also provides a binding platform for Factor I-mediated proteolysis of C3b, thereby limiting the AP [41]. Similarly, determination of the structure of the AP $\mathrm{C} 3$ convertase 


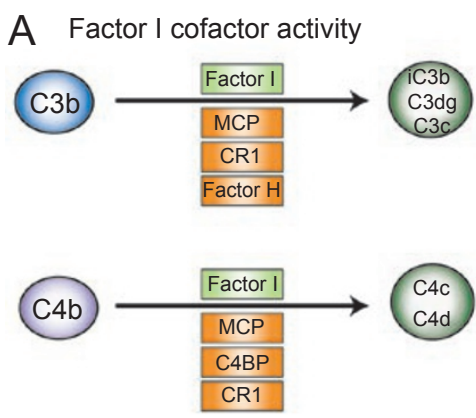

B Decay-accelerating activity for C3 convertases
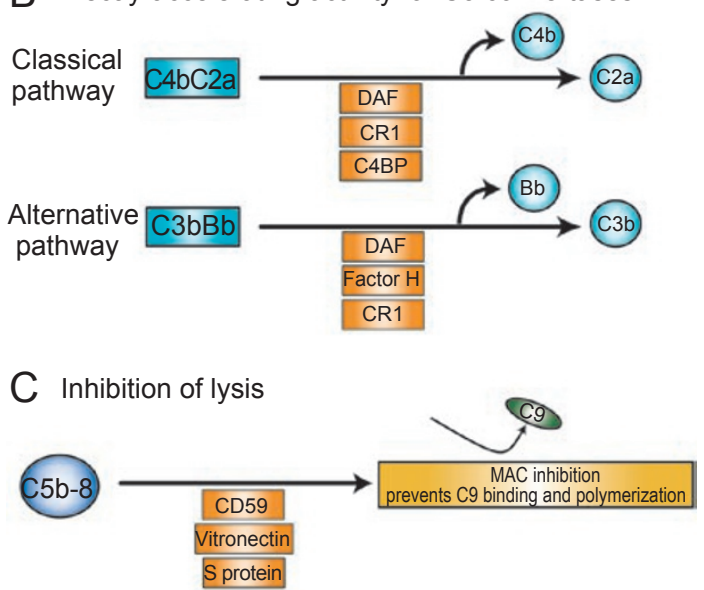

D Clevage of the anaphylatoxins

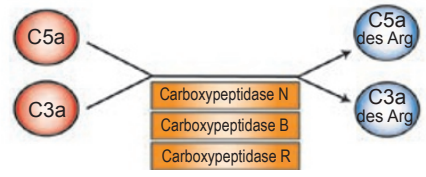

Figure 2 Complement regulation. Complement activity must be regulated to prevent bystander damage to the host. (A) Factor I-mediated cleavage of $\mathrm{C} 3 \mathrm{~b}$ and $\mathrm{C} 4 \mathrm{~b}$ prevents them from forming active convertases and requires cofactor activity, so that complement can be activated in appropriate contexts. These cofactors include the membrane-bound membrane cofactor protein (MCP) and complement receptor 1 (CR1), as well as the fluid-phase Factor $\mathrm{H}$ and $\mathrm{C} 4$-binding protein (C4BP). (B) C3 convertases are regulated by proteins containing decayaccelerating activity, which serve to inhibit assembly of new C3 convertases and shorten the half-life of the preformed convertases, limiting their ability to participate in complement activation. Proteins with decay-accelerating activity for the classical C3 convertase include decay-accelerating factor (DAF), CR1, and C4BP. AP inhibitors with this activity are DAF, Factor $\mathrm{H}$, and CR1. (C) The MAC is the lytic complex of complement and its assembly can be inhibited by the membrane-bound CD59 and the fluid-phase vitronectin and S protein. (D) Anaphylatoxins are very potent proinflammatory molecules and their activity is limited by removal of their $\mathrm{N}$-terminal arginine residue by serum carboxypeptidases, including carboxypeptidase $\mathrm{N}, \mathrm{B}$, and $\mathrm{R}$. Formation of the 'des-Arg' forms of C5a and C3a limits their ability to interact with their cognate receptors, C5aR and C3aR, respectively. stabilized by a bacterial immune-evasion protein staphylococcal complement inhibitor (SCIN) (discussed below) helped to elucidate mechanisms of both $\mathrm{C} 3$ convertase structure/function and microbial evasion strategies [42].

Host-specific protection is generally achieved by ensuring host-specific expression patterns of complement regulators. While many of the complement regulators are intrinsic membrane proteins in host cells, the fluid-phase inhibitor Factor $\mathrm{H}$ achieves host-specific protection by binding polyanions, such as sialic acid and heparin, which make up an essential component of eukaryotic, but not prokaryotic, cell surfaces $[38,43]$. The functional consequence of this mechanism is that Factor $\mathrm{H}$ is preferentially targeted to host surfaces, where it exerts cofactor and decay-accelerating activities to prevent $\mathrm{C} 3$ convertase formation and leads to the catabolism of $\mathrm{C} 3 \mathrm{~b}$ to its degradation products (e.g., iC $3 b, \mathrm{C} 3 \mathrm{dg}$ ). The final level of complement control, necessary in situations in which there is rampant complement activation, is to inhibit the assembly of the lytic MAC via of membranebound (CD59) or fluid-phase (vitronectin, S protein) inhibitors (Figure 2C) [38, 44]. Thus, the array of complement inhibitory proteins serves to check complement activation in the healthy host and upon complement activation as a response to infection, helping to confine the destructive activities of complement to appropriate surfaces to minimize bystander tissue damage.

\section{Effectors of the complement system}

Complement activation, regardless of the pathway, converges on the generation of three broad effector pathways that serve to enable the complement to fulfill its physiological imperatives in host defense: (1) direct lysis of targeted surfaces by way of the MAC assembly, (2) alerting and priming the immune system by way of the generation of potent proinflammatory anaphylatoxins, and (3) opsonization and clearance of target surfaces by way of the complement opsonins (C4b, C3b, C3bi) and engagement of CRs on phagocytic cells, such as macrophages and neutrophils (Figure 3) [1, 2, 11]. MAC assembly is germinated when $\mathrm{C} 3 \mathrm{~b}$, following its deposition on cell surfaces, associates with $\mathrm{C} 3$ convertases of all three pathways to form the $\mathrm{C} 5$ convertases; $\mathrm{C} 4 \mathrm{bC} 2 \mathrm{aC} 3 \mathrm{~b}$ (classical and lectin pathways) and $\mathrm{C} 3 \mathrm{bBbC} 3 \mathrm{~b}$ (AP) [2, 3]. $\mathrm{C} 5$ convertases are the staging points for the terminal complement activation and cleave C5 into anaphylatoxins $\mathrm{C} 5 \mathrm{a}$ and $\mathrm{C} 5 \mathrm{~b}$. C5b liberation exposes a binding site for $\mathrm{C} 6$, and the subsequent $\mathrm{C} 5 \mathrm{bC} 6$ binds reversibly to the targeted surfaces and forms the molecular foundation for the MAC (Figure 3A) [45]. C7 associates with C5bC6, creating $\mathrm{C} 5 \mathrm{~b}-7$, which is integrated into the phospholipid 
A MAC assembly

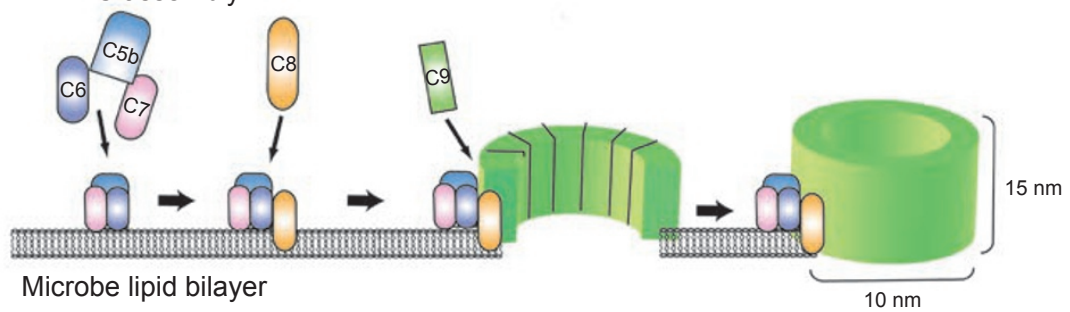

B Anaphylatoxins and inflammatory response

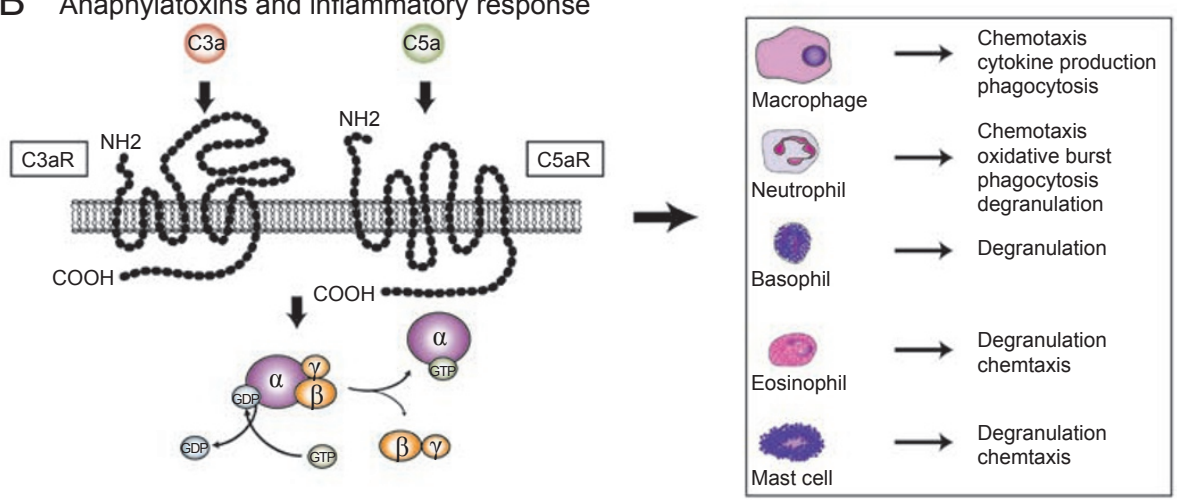

C Opsonization and phagocytosis

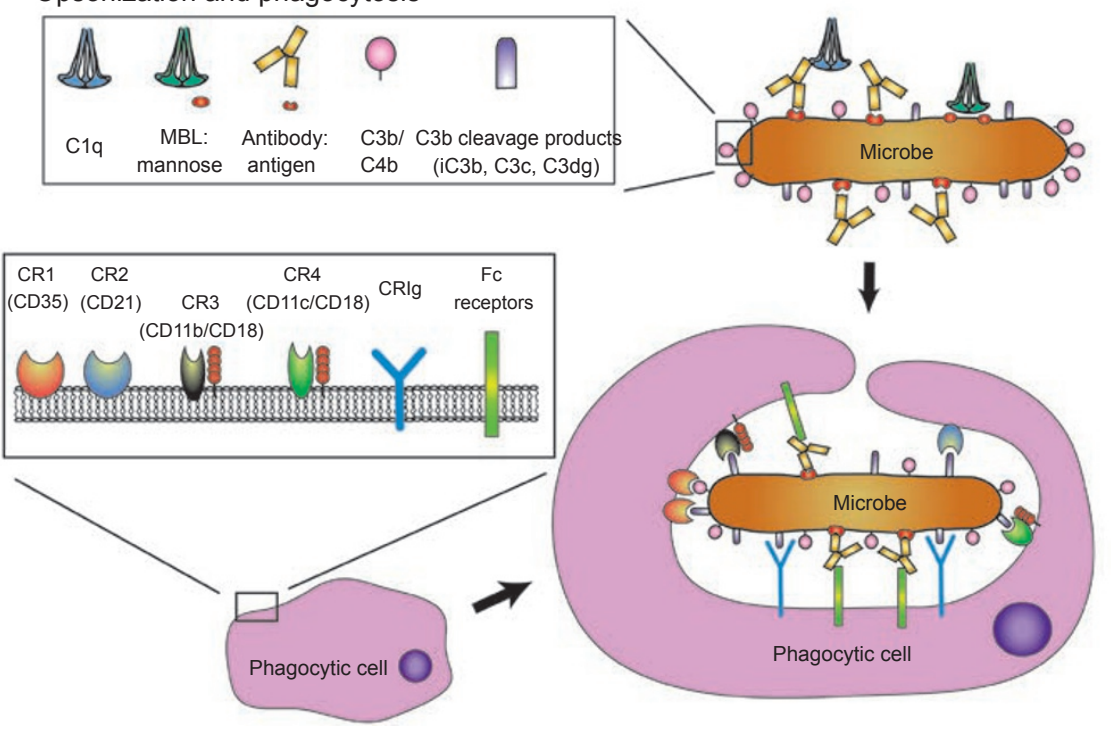

Figure 3 Effectors of the complement system. The function of complement in innate host defense is accomplished through three broad effector pathways; lysis, inflammation, and opsonization/phagocytosis. (A) Complement activation and the generation of $\mathrm{C} 5$ convertases lead to the liberation of the C5 product, C5b. C5b forms the basis of the MAC assembly. C5b first associates with $\mathrm{C} 6, \mathrm{C} 7$, and the targeted surface. $\mathrm{C} 8$ associates with this complex and is partially inserted into the membrane. This allows C9 to insert into the lipid bilayer, where approximately 12-15 C9 molecules will form a stably inserted pore with $\sim 10 \mathrm{~nm}$ diameter. Formation of the pore leads to the targeted lysis of the surface upon which it is assembled, accompanied with a dysregulation of ion concentrations across the membrane and loss of mitochondrial polarity. (B) Anaphylatoxins are potent proinflammatory molecules generated from the cleavage of C4, C3, and C5 into C4a, C3a, and C5a (C4a not shown), respectively. Binding of anaphylatoxins to the $\mathrm{N}$-terminal region of their cognate receptors, $\mathrm{C} 3 \mathrm{aR}$ and $\mathrm{C} 5 \mathrm{aR}$, allows conformational changes to the intracellular domains to induce G-protein coupling and downstream signaling. The effects of this binding depend on the cell type on which the anaphylatoxin receptor is expressed; and some of the most important cell types and effects in the innate immune response are summarized. (C) Generation of the C3b fragments by C3 convertases of all three activation pathways initiates the opsonization pathway of complement, an important effector in the 'tagging' and clearance of foreign bodies. Opsonic fragments, such as $\mathrm{C} 3 \mathrm{~b}$ and its cleavage products, are recognized by complement receptors 1-4 (CR1-4) and CRIg. Fc receptors bind to the Fc region of antibody. Binding of the complement receptors to opsonized bodies mediates their sequestration and uptake by phagocytic cells, most commonly macrophages and neutrophils. 
membrane bilayer and induces the membrane insertion of $\mathrm{C} 8 \alpha$ and $\mathrm{C} 8 \beta$, forming unstable pores. $\mathrm{C} 9$ binds to $\mathrm{C} 8 \alpha$ and initiates polymerization of multiple $\mathrm{C} 9$ molecules to form stable inserted pores with a maximum diameter of $10 \mathrm{~nm}$ (up to 13 C9 molecules) [45]. This C5b-9 complex is the fully formed MAC, and is effective in inducing cell lysis in a variety of targets through a multi-hit process. MAC lytic activity is characterized by a rapid increase in $\left[\mathrm{Ca}^{2+}\right]_{\mathrm{i}}$, followed by loss of both mitochondrial polarity and adenine nucleotide pools (e.g., ADP, ATP) [46]. Whether cell death is apoptotic or necrotic seems to be a function of C5b-9 quantity, and fragmentation of DNA has been detected in as little as $30 \mathrm{~min}$ after treatment with a lytic dosage of complement, illustrating the destructive potential of the terminal pathway of complement activation [45, 47].

MAC assembly and targeted lysis are vital effectors of the antipathogenic activities of complement, but certain pathogens have evolved mechanisms of self-protection that can limit the destructive potential and enable the pathogen to avoid persecution [48]. Therefore, it is crucial for complement activation to engage and recruit other components of the immune system through the generation of potent proinflammatory molecules that serve as both an alert signal to the immune system as a whole and also as potent chemoattractants to certain classes of leukocytes (Figure 3B). Anaphylatoxins, C3a, C4a, and $\mathrm{C} 5 \mathrm{a}$, are highly related, pleiotropic, proinflammatory molecules $\sim 9 \mathrm{kDa}$ in size (74-77 residues) generated as products of proteolytic activation of $\mathrm{C} 3, \mathrm{C} 4$, and $\mathrm{C} 5$ by upstream complement proteases, namely $\mathrm{C} 3$ convertase, activated $\mathrm{C} 1 \mathrm{~s}$, and $\mathrm{C} 5$ convertase, respectively $[2,3,49]$. Anaphylatoxin molecules are evolutionarily related to one another and as such share a relatively high degree of homology, as well as somewhat overlapping functions in the generation of the immune response [50]. C5a has been shown to be considerably more potent than $\mathrm{C} 3 \mathrm{a}$ and $\mathrm{C} 4 \mathrm{a}$ in inducing biologically relevant responses, with $\mathrm{C} 4 \mathrm{a}$ being the weakest to the extent that physiologically potent functions (in humans) and a cognate receptor have yet to be described for this molecule [51, 52]. Anaphylatoxins are potent phlogistic molecules whose physiological functions include many hallmark proinflammatory activities, such as increases in vascular permeability, smooth muscle contraction, leukocyte recruitment, and increases in other accoutrements of white blood-cell responses (e.g., chemotaxis, migration, and phagocytosis), as well as promoting the production and release of other inflammatory mediators (e.g., histamine) $[53,54]$.

The functional responses of anaphylatoxins are mediated by their interactions with cognate 7-transmembrane G-protein-coupled receptors (C3aR for C3a, C5aR/C5L2 for C5a) of the rhodopsin family [55-60]. Binding of anaphylatoxins to extracellular, N-terminal regions of the anaphylatoxin receptors allows conformational changes to the intracellular, C-terminal regions of the receptors, resulting in coupling to G-proteins, predominantly pertussis toxin-sensitive $G_{i \alpha}$, to induce downstream signaling cascades [61-65]. Activities of anaphylatoxins are confined by cell types that express their receptors, predominantly thought to be cells of myeloid origin, including granulocytes (basophils, eosinophils, and neutrophils), monocytes/macrophages, mast cells, and some dendritic cells, although there are numerous reports of receptor expression in a number of nonmyeloid cell types [54, 59, $60,66-73]$. Inactivation of anaphylatoxin molecules is an important determinant of the duration and extent of their potent functions and represents an alternative mechanism to control complement activation. Cleavage of the N-terminal arginine of both $\mathrm{C} 5 \mathrm{a}$ and $\mathrm{C} 3 \mathrm{a}$ by serum carboxypeptidases (i.e., carboxypeptidase N) rapidly converts each to the 'des-arg' form (Figure 2D) [2].

The third and final major effector arm enabling the activated complement cascade to protect the host from infection lies in the ability of phagocytic cells to recognize, ingest, and eliminate cells coated with opsonins generated as a result of complement activation (Figure 3C). Recognition of opsonic complement fragments, including Factor I-generated proteolytic fragments of $\mathrm{C} 3 \mathrm{~b}$ ( $\mathrm{iC} 3 \mathrm{~b}, \mathrm{C} 3 \mathrm{c}$, and $\mathrm{C} 3 \mathrm{dg}$ ), by phagocytic cells is accomplished through three families of CRs; the short consensus repeat module-containing CR1 and CR2, the $\beta_{2}$ integrin family members CR3 and CR4, and the immunoglobulin superfamily member CRIg $[74,75]$. CR1 (CD35) is a multifunctional receptor that is expressed in the majority of peripheral blood cells and binds with high affinity to $\mathrm{C} 4 \mathrm{~b}$ and $\mathrm{C} 3 \mathrm{~b}$, as well as to $\mathrm{iC} 3 \mathrm{~b}, \mathrm{C} 3 \mathrm{dg}$, $\mathrm{Clq}$, and mannose-binding protein [76-79]. Binding of CR1 to the complement opsonin fragments serves to mediate clearance of immune complexes, especially in erythrocytes, and to mediate phagocytosis by neutrophils and monocytes [79]. In addition to phagocytosis, interaction of CR1 with its ligands plays further roles in host defense against infection by promoting secretion of proinflammatory molecules, such as interleukin (IL)- $1 \alpha$, IL-1 $\beta$, and prostaglandins [80]. Furthermore, CR1 plays a role in antigen presentation to B cells and is also a potent inhibitor of both the classical pathway and the AP of complement activation by exhibiting decay-accelerating activity for both $\mathrm{C} 3$ and $\mathrm{C} 5$ convertases, as well as cofactor activity for Factor-I-mediated cleavage of $\mathrm{C} 3 \mathrm{~b}$ and C4b [79]. CR2 (CD21) is very similar to CR1, but lacks several $\mathrm{N}$-terminal domains important for the binding of $\mathrm{C} 3 \mathrm{~b} / \mathrm{C} 4 \mathrm{~b}$ and complement regulatory activities and 
will only bind to $\mathrm{iC} 3 \mathrm{~b} / \mathrm{C} 3 \mathrm{~d} / \mathrm{C} 3 \mathrm{dg}$ [81]. Nevertheless, it is the principal CR enhancing B-cell immunity and will be discussed at length below, along with similar adaptive immune functions for CR1. CR3 and CR4 are transmembrane heterodimers composed of an $\alpha$-subunit (CD11b or CD11c, respectively) and a common $\beta$-chain $(\mathrm{CD} 18)$ that belong to the integrin family and perform functions not only in the phagocytosis of opsonized surfaces but also in leukocyte trafficking, adhesion, migration, and costimulation, which all have important consequences in the defense of the host against pathogenic invasion [75, 82]. CRIg is a more recently identified CR of the immunoglobulin superfamily expressed on a restricted subset of tissue-resident macrophages, including the Kupffer cells in the liver [83]. Kupffer cells from CRIg-deficient mice are unable to efficiently clear C3-opsonized particles, resulting in increased mortality in the host in response to infection [83]. CRIg may represent an important component of phagocytosis not only in the reticuloendothelial system (of which the Kupffer cells are dominant) but also in other resident tissue macrophages, such as alveolar macrophages of the lung and foam cells in atherosclerotic plaques $[75,83]$.

The three terminal effector pathways of complement work in concert to protect the host from common pathogenic invasions. Many of the functions of complement activation take place through the use of germline-transmitted molecules that recognize relatively few pathogens, but are able to do so immediately and thus represent an important effector of the innate immune system. As discussed below, deficiency in these pathways leads to an impaired host immune response to common pathogens. However, the ability of complement to participate in host defense is not limited to these innate immune activities and effector systems of complement also contribute to efficient adaptive immune responses at several levels.

\section{Complement system in adaptive immunity: B-cell regulation and humoral immunity}

The aforementioned functions of the complement system, oposonization, lysis, and generation of the inflammatory response through soluble mediators, are paradigmatic and represent a well-characterized component of an innate host defense. It has become increasingly appreciated that complement functions in host defense extend beyond innate immune responses. The finding that B lymphocytes bound C3 raised the question as early as in the 1970 s as to whether the complement system was involved in adaptive immune responses [84]. Subsequent work demonstrated that depletion of $\mathrm{C} 3$ impaired humoral immune responses and provided direct evidence that efficient adaptive responses were contingent on an intact complement system in some cases [85]. Further study in animals bearing natural complement deficiencies implicated the classical pathway as a crucial mechanism for efficient antigen trapping and retention in lymphoid tissues (e.g., splenic follicles), suggesting that a major function of the complement system was to localize foreign antigens into immune sites important for lymphocytes responses [86-88].

The humoral arm of the adaptive immune response is tasked with protecting extracellular spaces through the generation of effector and memory B cells, and Bcell-produced antibodies, leading to neutralization and opsonization of pathogen and providing immunological memory against reinfection. The potency of this response stems from a complex interplay of immune mechanisms, contingent on the strength of antigenic stimuli and the presence of helper T-cell assistance, among many other factors [2]. Complement effectors are engaged with humoral immunity at multiple stages of B-cell differentiation and can influence B-cell biology on several levels [89, 90]. As alluded to previously, complement enhances Bcell immunity principally through CRs, CR1 (CD35) and CR2 (CD21), expressed on B lymphocytes and follicular dendritic cells (FDCs), and binding to the complement opsonins in a concerted effort with the phagocytic system $[75,90,91]$. CR2 forms a receptor complex with the signaling protein CD19 and the tetraspan protein CD81 to form the B-cell coreceptor complex (CD21-CD19CD81), which supports an enhanced signal via the B-cell receptor (BCR; e.g., surface immunoglobulin) when it encounters antigen coated with complement opsonins (e.g., C3d), resulting in the reduction of B-cell activation threshold by several orders of magnitude $[92,93]$. Thus, complement can be viewed as a 'natural adjuvant' and as an instructor of the humoral immune response [94].

The functional consequence of this modulation of B-cell signaling can be observed in multiple settings. B cells first express the CD21-CD19-CD81 coreceptor as they migrate from the bone marrow into the periphery, generally referred to as the transitional stage that has important implications in the elimination of self-reactive $\mathrm{B}$ cells and in the positive selection of B1 cells [95]. B1 cells, which are the chief sources of natural antibody with repertoires that are highly biased toward conserved antigens (e.g., nuclear antigens), are a long-lived and physiologically distinct population of B cells [2]. Complement seems to function in the selection and maintenance of B1 cells, as CR2-deficient mice have an altered repertoire of natural antibody, which can be observed by a marked reduction in injury following ischemia/reperfusion despite normal levels of IgM $[96,97]$. These mice also have re- 
duced numbers of B1a cells and show impaired generalized antibody production [98].

In addition to modulating B1 activity and the production of natural antibodies, cross-linking of the CD21CD19-CD81 coreceptor complex with BCR enhances B-cell immunity in later stages of B-cell differentiation as well. Coupling $\mathrm{C} 3 \mathrm{~d}$ to low-affinity antigen, which (if uncoupled) would cause B-cell death, results in not only survival but also B-cell activation and production of antibody, suggesting a role of complement in the 'instruction' of naive B cells in the periphery [99]. Similarly, activation of mature peripheral and follicular B cells by complement-opsonized antigen leads to their migration to the lymphoid T-cell:B-cell boundary, where helper $\mathrm{T}$ cells provide costimulation via CD40, leading to B-cell activation and expansion. Subsequently, activated B cells initiate the formation of germinal centers (GCs), where CRs on B cells enhance BCR signaling, leading to effective differentiation into plasma and memory B cells [89, 90]. This is supported by the observation that antigenspecific B cells lacking CR1/CR2 fail to survive within a GC when put in competition with WT B cells, insinuating that coreceptor signaling is vital to clonal selection of B cells and in the absence of this complement-assisted cosignaling, B cells fail to compete and undergo cell death [100]. FDCs are central to this process as they are specialized stromal cells that secrete the B-lymphocyte chemoattractant, help to organize GCs, and provide effective means of trapping and retaining antigen within $\mathrm{B}$-cell follicles and displaying them to both naive and GC B cells [101]. FDCs express relatively high levels of $\mathrm{CR} 1$ and $\mathrm{CR} 2$ and effectively retain C3-coated immune complexes within the lymphoid follicles, promoting the antigen selection of high-affinity GC B cells [92]. Furthermore, post-GC B cells require complement on FDCs for an efficient maintenance of long-term memory B cells, affinity maturation, and effective recall responses [102].

In addition to the CRs, CR1 and CR2, some evidence suggests a role of anaphylatoxins in the modulation of $\mathrm{B}$ cell biology. B cells have been reported to express C3aR; and both ligands, $\mathrm{C} 3 \mathrm{a}$ and $\mathrm{C} 3 \mathrm{a}_{\text {desArg }}$, have been shown to negatively regulate the polyclonal immune response, as well as limit the secretion of TNF- $\alpha$ and IL-6 [103, 104]. Conversely, C5a has been reported to play a role in the trafficking and migration of various B-cell populations, including GC B cells and tonsillar memory and naïve B cells [105-107].

The roles of complement in humoral immunity can be illustrated by the characterization of mice bearing deficiencies in both complement components and CRs [90]. Studies have demonstrated the importance of an intact complement classical pathway $(\mathrm{C} 1 \mathrm{q}, \mathrm{C} 3$, or $\mathrm{C} 4)$ in humoral response to both thymus-dependent and thymus-independent antigens [108]. In many cases, mice deficient in CR1/2 (a single gene Crl/2 encodes both proteins in mice) exhibit similar impairment, suggesting that pro-humoral responses are mediated by these receptors [89]. For example, mice deficient in CR $1 / 2$ and C3 exhibited markedly reduced IgM (and $\operatorname{IgG}$ ) levels, failure in isotype switch to $\mathrm{IgG}$, and decreased antigen uptake in response to T-independent type II polysaccharide antigens $[109,110]$. Similar results were established for Tdependant antigens, such as keyhole limpet hemocyanin and bacteriophage $\Phi \mathrm{X} 174$, as well as viral and bacterial pathogens, such as herpes simplex virus, West Nile virus, and Streptococcus pneumoniae [98, 111-114]. These and other studies highlight the critical role complement plays in the generation of robust antibody response at several levels of B-cell biology.

\section{Complement system in adaptive immunity: T-cell immunity}

In view of the impressive repertoire of activities mediated by complement that influence the generation of effective humoral responses, involvement of complement in the other wing of adaptive immunity, the T-cell response, would be expected. Indeed, Janeway's conceptualization of the 'adjuvant effect' being due to the influence of the innate immune system on acquired immunity, nearly two decades ago, provided a framework for studying the contributions of innate immunity to T-cell-mediated immune responses [115]. Initially, it was suggested that complement was much more important in B-cell biology as many of the complement/CR-deficient models developed apparently normal T-cell responses, yet humoral responses were impaired $[112,116]$. However, the finding that priming of both CD4 and CD8 T cells was reduced in $\mathrm{C} 3$-deficient mice during pulmonary influenza challenge suggested a more generalized role of complement [117]. A potential role of complement in Tcell immune responses to viral and alloantigens has now been demonstrated in a number of other studies [118-121]. The mechanisms of this influence are not as well characterized as those related to humoral immunity, and as such represent a crucial area of study in understanding the roles complement plays in regulating adaptive immune responses.

Characterization of the potential role of complement in T-cell immunity has been facilitated by the use of a DAF-deficient mouse model [122, 123]. DAF deficiency led to increased complement activation in various in vivo settings, and this presumably allowed the potential modulating effect of complement on T-cell immunity to 
be amplified and more easily detectable than otherwise in normal mice. For example, it has been shown that DAFdeficient mice present with an enhanced $\mathrm{T}_{\mathrm{H}} 1$ response characterized by hypersecretion of interferon- $\gamma$ and IL-2 and suppression of IL-10 following antigen restimulation $[122,123] . \mathrm{DAF}^{-/-}$mice also showed heightened pathology in the mouse model of multiple sclerosis, experimental autoimmune encephalomyelitis $[122,124]$. Furthermore, $\mathrm{DAF}^{-/}$mice displayed an enhanced T-cell immune response in a model of lymphocytic choriomeningitis virus (LCMV) infection [120]. While the phenotype of increased T-cell immunity in $\mathrm{DAF}^{-/}$mice seems clear and unquestionable, the underlying mechanism that contributes to this phenotype remains to be determined. One hypothesis is that in the absence of DAF, AP complement activation on APCs and T cells is increased leading to more local anaphylatoxin production. Subsequent engagement of $\mathrm{C} 3 \mathrm{aR} / \mathrm{C} 5 \mathrm{aR}$ within the immunological synapse then provides a costimulatory signal for T-cell survival and activation $[125,126]$. AP-mediated production of $\mathrm{C} 3 \mathrm{a}$ and engagement of $\mathrm{C} 3 \mathrm{aR}$ have also been proposed to occur in normal (i.e., wild-type) mouse APCs where DAF is intact [127]. Such C3aR-triggered signaling in APCs was believed to involve cAMP as a second messenger and contribute to the regulation of APC maturation and antigen uptake $[119,121]$. One issue that could potentially contradict these hypotheses, and thus remains to be resolved by more careful studies, is whether anaphylatoxin receptors are actually expressed in T cells and professional APCs (i.e., dendritic cells), as there are some contradictory reports on this issue [72, 128-131].

At the whole animal level, C5aR has been shown to be essential for the modulating effect of complement on T-cell immunity in various models. For example, it has been demonstrated that mice treated with $\mathrm{C} 5 \mathrm{aR}$ antagonists produced fewer antigen-specific CD8 T cells, following infection with influenza type A [118]. This agrees with the finding that DAF-deficient mice present with an enhanced naïve and memory $\mathrm{CD} 8^{+} \mathrm{T}$-cell response in reaction to infection with LCMV contingent on the presence of $\mathrm{C} 3$ or $\mathrm{C} 5 \mathrm{aR}$ [120]. Adding further support is the observation that mice bearing a targeted C5aR deficiency show reduced response to pulmonary infections with Pseudomonas aeruginosa, characterized by impaired pulmonary clearance, despite seemingly normal neutrophilic infiltration [132]. C5aR has also been shown in mice to mediate a synergistic effect with Toll-like receptor (TLR)-4 in eliciting a stronger inflammatory response with signaling from both innate immune receptors than with either alone [133]. This link is credible because, like complement, the TLR system recognizes conserved pathogenic motifs and is often activated simultaneously with the complement system, indicating that it is plausible that these two effectors of the innate immune system may cooperate in their functions with potential effects on T-cell immune responses [134, 135].

Complement inhibitory proteins, namely MCP, DAF, and CR1, have also been implicated in the direct modulation of APC or T-cell function. Cross-linking of CD46 on macrophages by certain pathogenic antigens, such as the pili from Nesseria or Hemagglutinin from measles virus leads to the impairment of IL-12 production by APCs $[136,137]$. The measles virus is notorious for suppressing T-cell responses during the course of infection, and the suppression of IL-12 production by APCs through subversion of CD46 may be one such mechanism for this pathogenic activity [137]. Cross-linking of CR1, which has regulatory properties discussed previously, on $\mathrm{T}$ cells has been shown to inhibit proliferation and reduce IL-2 production [138]. DAF, in addition to those roles seen previously in suppressing T-cell responses in vivo, may also play a role in costimulation. It has been reported that the coengagement of DAF and CD3 results in the proliferation of CD4 $\mathrm{T}$ cells, indicating that the role $\mathrm{DAF}$ plays in T-cell biology is, at best, multifaceted [139].

Overall, these results serve to illustrate a functional role of complement activation with regard to T-cell biology. There seems to be sufficient evidence supporting a link between complement activation and enhanced T-cell immune response at the organismal level. Although various hypotheses have been proposed, there is yet to be a consensus regarding the precise mechanism by which complement regulates T-cell immunity. Ongoing studies in this field should provide an improved understanding of this question and contribute to the development of complement-based therapeutic strategies in human diseases relating to microbial infection, autoimmune disorders, and organ transplantation.

\section{Complement evasion/subversion strategies of mi- croorganisms}

Infectious diseases represent a major health, social, and economic burden. The importance of complement to host defense, and the control of infection, as a whole can be appreciated by the consequences observed when complement functions are compromised as a result of genetic deficiency, pathogenic interference, or other mechanisms. Given that complement has coevolved with pathogens for millions of years, it is perhaps not surprising to find that pathogens have developed mechanisms to inhibit complement activation and effector functions, thereby subverting or avoiding this powerful component 
of innate immunity and increasing their ability to survive and replicate within the host. Given the disease burden associated with infection with microorganisms and the requirement of novel and effective antibiotics in order to combat them, the study of complement and its roles in defense has significant clinical implications.

As discussed throughout, animals deficient in various complement components have a variety of phenotypes related to host defense, including increased susceptibility to infection, impaired T- and B-cell responses, reduction in phagocytic activity, and ability to clear pathogens and other immune complexes, among many others. In humans, individuals deficient in one of the major complement effector pathways, most commonly opsonization and lytic pathways, present with increased susceptibility to infection $[1,11,140]$. Deficiency or defect in opsonization pathways, including the production of antibody and phagocytic ability, results in early and recurrent infections with pyrogenic bacteria with the most common organisms being $S$. pneumoniae and Haemophilus influenzae [1]. Defect in the assembly or function of the MAC, or deficiency in the components needed for its generation, is associated with neisserial disease, especially infection with Neisseria meningitidis [141]. Due to the central role of C3 in the complement system, deficiency of $\mathrm{C} 3$ results in defects in both opsonization and lysis, and thus is strongly associated with recurrent infections by the organisms mentioned above [140]. Deficiency of AP components properdin and Factor $\mathrm{D}$ is rare, but is also a risk factor in some cases for infection with the same organisms as $\mathrm{C} 3$ deficiency, while deficiency in unique classical pathway components (e.g., C1q, C2, C4) are more strongly associated with immune complex disease and the development of autoimmunity [140]. Interestingly, endemic meningococcal infections are associated with deficiency of MAC proteins, especially $\mathrm{C} 6$, in which prevalence of meningococcal infection is increased but mortality is decreased [142]. Finally, deficiency of MBL predisposes children to recurrent pyrogenic infection the ages of which $(6$ months to 2 years) suggest that the MBL is critical during the interval between the loss of passively acquired maternal antibody and maturation of their personal immune system $[1,143]$. Therefore, complement is indispensable for host defense against certain pathogens and represents an effective innate defense against common infections.

Many organisms, recognizing the potency of complement activity, have devised strategies to circumvent or subvert complement to increase survival or enhance their virulence. A given pathogen may utilize multiple strategies and molecules to evade host complement attack, as overcoming the powerful, immediate role of complement is imperative from a pathogenic perspective. Bacteria can interfere with complement on nearly every level of complement activation [144]. Staphylococcus aureus produces a membrane protein, Staphylococcal protein A $(\mathrm{SpA})$, whose predominant biological function is the binding to the $\mathrm{Fc}$ region of $\mathrm{IgG}$, which not only is effective in inhibiting Fc-receptor-mediated phagocytosis but also is highly capable of limiting complement activation via the classical pathway by interfering with the binding of C1q [145]. Similar immunoglobulin-binding proteins, such as protein $\mathrm{G}$ and protein $\mathrm{L}$ can be found in an array of other pathogens [144]. S. aureus also excretes a model pathogenic complement inhibitor called the SCIN that blocks all complement pathways by efficient inhibition of $\mathrm{C} 3$ convertases, preventing opsonization, phagocytosis, and by killing human neutrophils through an interesting interaction with C3 convertases [146]. Furthermore, opsonization by $\mathrm{C} 3$ fragments can be inhibited. For instance, Pseudomonas aeruginosa secretes active proteases that cleave $\mathrm{C} 3 \mathrm{~b}$ and prevent $\mathrm{C} 3 \mathrm{~b}$ deposition, and $S$. aureus cleaves surface-bound $\mathrm{C} 3 \mathrm{~b}, \mathrm{iC} 3 \mathrm{~b}$, and $\mathrm{IgG}$ through the conversion of plasminogen to the active protease plasmin on its cell surface by staphylokinase [144, 147]. Inhibition of MAC assembly and reduction of cytolytic ability can be achieved simply by virtue of having a thick cell wall, as is the case for Gram-positive bacteria $[148,149]$. In other cases, pathogens can inhibit the assembly or function of the MAC as in the case of Borrelia burgdorferi, which encodes a $80 \mathrm{kDa}$ surface protein that shares functional similarities with human CD59, the inhibitor of MAC assembly [150].

Pathogens utilize other mechanisms to escape complement as well. They may interact with host regulators, such as binding Factor $\mathrm{H}$, which increases the degradation of $\mathrm{C} 3 \mathrm{~b}$ and reduces formation of $\mathrm{C} 3$ convertase, thereby limiting complement activity [151]. This phenomenon is well characterized in the Nesseria family of pathogens, including $N$. meningitidis and $N$. gonorrhoeae, both of which have been shown to bind to Factor $\mathrm{H}$ in an attempt to avoid destruction by the host complement system $[42,152]$. Interestingly, recent structural determinations of the $N$. meningitidis: Factor H complex have revealed that the pathogen subverts the host complement system through the use of protein mimetics of host carbohydrate motifs, thereby recruiting Factor $\mathrm{H}$ to its surface and evading destruction [153]. In addition to Factor $\mathrm{H}$ binding, both viruses and bacteria may incorporate or recruit other host complement regulatory proteins, encode structural mimics of complement regulatory proteins, or simply encode unique regulatory proteins that serve to inhibit complement activity and thereby render the pathogen resistant to complement effectors [144, 
154]. Alternatively, pathogens may inhibit chemotaxis and recruitment of leukocytes by interfering with receptors that mediate these activities, most notably C5aR and the related formyl peptide receptor [144]. The chemotaxis inhibitory protein of $S$. aureus (CHIPS) is able to inhibit neutrophil chemotaxis and activation specifically, and represents an additional mechanism pathogens may utilize to escape complement $[155,156]$.

Some pathogens go further and subvert the complement system in order to enhance their virulence. This was alluded to previously when discussing the complement regulatory protein CD46, which was first described as a receptor for the measles virus and may contribute to the ability of measles to suppress the immune system [137, 157]. CD46 may also act as a cellular receptor for major bacterial strains, including $N$. gonorrhoeae and $N$. meningitidis $[158,159]$. DAF is a receptor for many picornaviruses, such as echoviruses and coxsakieviruses, which use different binding locations on DAF and require accessory molecules such as ICAM-1 in order to internalize $[160,161]$. CR2, as discussed above, plays a crucial role in $\mathrm{B}$ cells in the binding of $\mathrm{C} 3$ fragments. The EpsteinBarr virus has been shown to utilize CR2 as a cellular receptor for its envelope glycoprotein gp350/220, which may help to explain the tropism of this virus, due to the cellular distribution of CR2, as well as the lymphoproliferative aspects that may result in Burkitt's lymphoma [1, 162]. Human immunodeficiency virus exploits complement on multiple levels to increase its virulence [163]. It activates complement in the absence of antibody, which seems counterintuitive as this would normally result in virolysis. However, this is avoided by complement regulators contained in the viral membrane including DAF, which is subverted during the budding process from infected cells, and Factor $\mathrm{H}$, which is attached secondarily [163]. Furthermore, C3b deposition allows the virus to utilize CRs to enhance the efficiency of infection [163].

\section{Conclusions}

The role of complement in the immune system, and consequently on human health, has expanded dramatically. It is a well-characterized and an evolutionarily ancient component of host defense, impairment of which leads to susceptibility to infection. It has the ability to recognize well-conserved antigens derived from common pathogens, and to do so immediately and robustly. Activation of proteolytic cascades leads to the identification and persecution of the surface identified as foreign and allows complement to contain, control, and finally clear invading microorganisms. In performing these functions, complement represents a cornerstone of the innate defense against infection and provides a vital first-line barrier to invading pathogens. It is not surprising that the most evolutionarily successful pathogens have developed ways to circumvent or subvert complement in order to utilize host resources. The ways in which pathogens manipulate complement continue to be uncovered at a rapid rate and represent an exciting avenue of research. Further understanding of host-pathogen interactions and the roles complement plays in these interactions may help to develop more effective pharmacological agents against infection and reduce health-care burden.

On top of these important contributions to innate immunity, complement plays a vital role in shaping adaptive immune responses, functionally integrating it into the ability of the host to combat invasion from a wide range of pathogens. Since complement represents such an evolutionarily well-conserved mechanism of host defense, it is not surprising to find that it has been integrated into the relatively newer acquired immune responses. Complement has now been shown to play a role in both B- and T-cell responses at the organismal level. However, the exact mechanism(s) by which complement mediates T-cell immunity has yet to be determined. A careful, integrated study of complement effects on B- and T-cell biology will provide valuable insight into the in vivo biology of complement and may have implications for infectious disease as well as immunological disorders, such as in the cases of multiple sclerosis and organ transplantation.

In conclusion, complement is a multifaceted and robust effector, which bridges the innate and adaptive immune systems. It is vital to host defense, and the extent of its influence is becoming increasingly appreciated as additional information regarding the far-reaching effects of its activation is uncovered. Further study should produce significant dividends in our understanding of host defense as an integrated process and the roles complement plays in bridging innate and adaptive immunity.

\section{Acknowledgments}

We thank T Miwa and Y Kimura for critical evaluation of the figures. JRD is supported by a predoctoral fellowship from the American Heart Association (AHA). WCS is supported by grants from the National Institutes of Health (NIH).

\section{References}

1 Walport MJ. Complement. First of two parts. $N$ Engl J Med 2001; 344:1058-1066.

2 Janeway CA Jr, Travers P, Walport M, Shlomchik M. Immunobiology: The Immune System in Health and Disease. 6th Edition. New York: Garland Publishing, 2005.

3 Volanakis JE, Frank MM. The Human Complement System in 
Health and Disease. New York: Marcel Dekker Inc., 1998.

4 Jensen JA, Festa E, Smith DS, Cayer M. The complement system of the nurse shark: hemolytic and comparative characteristics. Science 1981; 214:566-569.

5 Suzuki MM, Satoh N, Nonaka M. C6-like and C3-like molecules from the cephalochordate, amphioxus, suggest a cytolytic complement system in invertebrates. J Mol Evol 2002; 54:671-679.

6 Azumi K, De Santis R, De Tomaso A, et al. Genomic analysis of immunity in a Urochordate and the emergence of the vertebrate immune system: "waiting for Godot". Immunogenetics 2003; 55:570-581.

7 Al-Sharif WZ, Sunyer JO, Lambris JD, Smith LC. Sea urchin coelomocytes specifically express a homologue of the complement component C3. J Immunol 1998; 160:2983-2997.

8 Zhu Y, Thangamani S, Ho B, Ding JL. The ancient origin of the complement system. EMBO J 2005; 24:382-394.

9 Miller DJ, Hemmrich G, Ball EE, et al. The innate immune repertoire in cnidaria-ancestral complexity and stochastic gene loss. Genome Biol 2007; 8:R59.

$10 \mathrm{Du}$ Pasquier L, Litman GW. Origin and Evolution of the Vertebrate Immune System. Berlin: Springer Edition, 2000.

11 Walport MJ. Complement. Second of two parts. $N$ Engl J Med 2001; 344:1140-1144.

12 Medzhitov R, Janeway C Jr. Innate immunity. $N$ Engl J Med 2000; 343:338-344.

13 Medzhitov R, Janeway CA Jr. Decoding the patterns of self and nonself by the innate immune system. Science 2002; 296:298-300.

14 Gordon S. Pattern recognition receptors: doubling up for the innate immune response. Cell 2002; 111:927-930.

15 Epstein J, Eichbaum Q, Sheriff S, Ezekowitz RA. The collectins in innate immunity. Curr Opin Immunol 1996; 8:29-35.

16 Fujita T, Endo Y, Nonaka M. Primitive complement systemrecognition and activation. Mol Immunol 2004; 41:103-111.

17 Harmat V, Gal P, Kardos J, et al. The structure of MBL-associated serine protease-2 reveals that identical substrate specificities of C1s and MASP-2 are realized through different sets of enzyme-substrate interactions. J Mol Biol 2004; 342:15331546.

18 Bally I, Rossi V, Lunardi T, et al. Identification of the C1qbinding sites of human $\mathrm{C} 1 \mathrm{r}$ and $\mathrm{C} 1 \mathrm{~s}$ : a refined three-dimensional model of the $\mathrm{C} 1$ complex of complement. $J$ Biol Chem 2009; 284:19340-19348.

19 Gal P, Barna L, Kocsis A, Zavodszky P. Serine proteases of the classical and lectin pathways: similarities and differences. Immunobiology 2007; 212:267-277.

20 Matsushita M, Endo Y, Fujita T. MASP1 (MBL-associated serine protease 1). Immunobiology 1998; 199:340-347.

21 Dahl MR, Thiel S, Matsushita M, et al. MASP-3 and its association with distinct complexes of the mannan-binding lectin complement activation pathway. Immunity 2001; 15:127-135.

22 Takahashi M, Iwaki D, Kanno K, et al. Mannose-binding lectin (MBL)-associated serine protease (MASP)-1 contributes to activation of the lectin complement pathway. J Immunol 2008; 180:6132-6138

23 Dobo J, Harmat V, Beinrohr L, et al. MASP-1, a promiscuous complement protease: structure of its catalytic region reveals the basis of its broad specificity. J Immunol 2009; 183:1207-
1214

24 Hourcade DE. Properdin and complement activation: a fresh perspective. Curr Drug Targets 2008; 9:158-164.

25 Paques EP, Scholze H, Huber R. Purification and crystallization of human anaphylatoxin, C3a. Hoppe Seylers $Z$ Physiol Chem 1980; 361:977-980.

26 Nagar B, Jones RG, Diefenbach RJ, Isenman DE, Rini JM. $\mathrm{X}$-ray crystal structure of $\mathrm{C} 3 \mathrm{~d}$ : a C3 fragment and ligand for complement receptor 2. Science 1998; 280:1277-1281.

27 Janssen BJ, Huizinga EG, Raaijmakers HC, et al. Structures of complement component $\mathrm{C} 3$ provide insights into the function and evolution of immunity. Nature 2005; 437:505-511.

28 Milder FJ, Gomes L, Schouten A, et al. Factor B structure provides insights into activation of the central protease of the complement system. Nat Struct Mol Biol 2007; 14:224-228.

29 Torreira E, Tortajada A, Montes T, Rodriguez de Cordoba S, Llorca O. 3D structure of the $\mathrm{C} 3 \mathrm{bB}$ complex provides insights into the activation and regulation of the complement alternative pathway convertase. Proc Natl Acad Sci USA 2009; 106:882-887.

30 Krishnan V, Xu Y, Macon K, Volanakis JE, Narayana SV. The crystal structure of $\mathrm{C} 2 \mathrm{a}$, the catalytic fragment of classical pathway $\mathrm{C} 3$ and $\mathrm{C} 5$ convertase of human complement. $J$ Mol Biol 2007; 367:224-233.

31 Hourcade DE. The role of properdin in the assembly of the alternative pathway $\mathrm{C} 3$ convertases of complement. $J$ Biol Chem 2006; 281:2128-2132.

32 Spitzer D, Mitchell LM, Atkinson JP, Hourcade DE. Properdin can initiate complement activation by binding specific target surfaces and providing a platform for de novo convertase assembly. J Immunol 2007; 179:2600-2608.

33 Kimura Y, Miwa T, Zhou L, Song WC. Activator-specific requirement of properdin in the initiation and amplification of the alternative pathway complement. Blood 2008; 111:732740 .

34 Huber-Lang M, Sarma JV, Zetoune FS, et al. Generation of $\mathrm{C} 5 \mathrm{a}$ in the absence of $\mathrm{C} 3$ : a new complement activation pathway. Nat Med 2006; 12:682-687.

35 Markiewski MM, Nilsson B, Ekdahl KN, Mollnes TE, Lambris JD. Complement and coagulation: strangers or partners in crime? Trends Immunol 2007; 28:184-192.

36 Liszewski MK, Farries TC, Lublin DM, Rooney IA, Atkinson JP. Control of the complement system. Adv Immunol 1996; 61:201-283.

37 Sim RB, Day AJ, Moffatt BE, Fontaine M. Complement factor I and cofactors in control of complement system convertase enzymes. Methods Enzymol 1993; 223:13-35.

38 Turnberg D, Botto M. The regulation of the complement system: insights from genetically-engineered mice. Mol Immunol 2003; 40:145-153.

39 Sharma AK, Pangburn MK. Identification of three physically and functionally distinct binding sites for $\mathrm{C} 3 \mathrm{~b}$ in human complement factor $\mathrm{H}$ by deletion mutagenesis. Proc Natl Acad Sci USA 1996; 93:10996-11001.

40 Seya T, Hirano A, Matsumoto M, Nomura M, Ueda S. Human membrane cofactor protein (MCP, CD46): multiple isoforms and functions. Int J Biochem Cell Biol 1999; 31:1255-1260.

$41 \mathrm{Wu}$ J, Wu YQ, Ricklin D, et al. Structure of complement fragment $\mathrm{C} 3 \mathrm{~b}$-factor $\mathrm{H}$ and implications for host protection by 
complement regulators. Nat Immunol 2009; 10:728-733.

42 Rooijakkers SH, Wu J, Ruyken M, et al. Structural and functional implications of the alternative complement pathway $\mathrm{C} 3$ convertase stabilized by a staphylococcal inhibitor. Nat Immunol 2009; 10:721-727.

43 Blackmore TK, Hellwage J, Sadlon TA, et al. Identification of the second heparin-binding domain in human complement factor H. J Immunol 1998; 160:3342-3348.

44 Meri S, Morgan BP, Davies A, et al. Human protectin (CD59), an 18,000-20,000 MW complement lysis restricting factor, inhibits $\mathrm{C} 5 \mathrm{~b}-8$ catalysed insertion of $\mathrm{C} 9$ into lipid bilayers. Immunology 1990; 71:1-9.

45 Esser AF. The membrane attack complex of complement. Assembly, structure and cytotoxic activity. Toxicology 1994; 87:229-247.

46 Papadimitriou JC, Ramm LE, Drachenberg CB, Trump BF, Shin ML. Quantitative analysis of adenine nucleotides during the prelytic phase of cell death mediated by C5b-9. J Immunol 1991; 147:212-217.

47 Cragg MS, Howatt WJ, Bloodworth L, et al. Complement mediated cell death is associated with DNA fragmentation. Cell Death Differ 2000; 7:48-58.

48 Frank MM. Annihilating host defense. Nat Med 2001; 7:12851286.

49. Hugli TE, Muller-Eberhard HJ. Anaphylatoxins: C3a and C5a. Adv Immunol 1978; 26:1-53.

50 Sunyer JO, Boshra H, Li J. Evolution of anaphylatoxins, their diversity and novel roles in innate immunity: insights from the study of fish complement. Vet Immunol Immunopathol 2005; 108:77-89.

51 Ember JA, Hugli TE. Complement factors and their receptors. Immunopharmacology 1997; 38:3-15.

52 Lienenklaus S, Ames RS, Tornetta MA, et al. Human anaphylatoxin $\mathrm{C} 4 \mathrm{a}$ is a potent agonist of the guinea pig but not the human C3a receptor. J Immunol 1998; 161:2089-2093.

53 Haas PJ, van Strijp J. Anaphylatoxins: their role in bacterial infection and inflammation. Immunol Res 2007; 37:161-175.

54 Wetsel RA. Structure, function and cellular expression of complement anaphylatoxin receptors. Curr Opin Immunol 1995; 7:48-53.

55 Hsu MH, Ember JA, Wang M, et al. Cloning and functional characterization of the mouse $\mathrm{C} 3 \mathrm{a}$ anaphylatoxin receptor gene. Immunogenetics 1997; 47:64-72.

56 Hollma TJ, Haviland DL, Kildsgaard J, Watts K, Wetsela RA. Cloning, expression, sequence determination, and chromosome localization of the mouse complement C3a anaphylatoxin receptor gene. Mol Immunol 1998; 35:137-148.

57 Bao L, Gerard NP, Eddy RL Jr, Shows TB, Gerard C. Mapping of genes for the human C5a receptor (C5AR), human FMLP receptor (FPR), and two FMLP receptor homologue orphan receptors (FPRH1, FPRH2) to chromosome 19. Genomics 1992; 13:437-440.

58 Haviland DL, McCoy RL, Whitehead WT, et al. Cellular expression of the $\mathrm{C} 5 \mathrm{a}$ anaphylatoxin receptor $(\mathrm{C} 5 \mathrm{aR})$ : demonstration of $\mathrm{C} 5 \mathrm{aR}$ on nonmyeloid cells of the liver and lung. $J$ Immunol 1995; 154:1861-1869.

59 Monk PN, Scola AM, Madala P, Fairlie DP. Function, structure and therapeutic potential of complement $\mathrm{C} 5$ a receptors. $\mathrm{Br} J$ Pharmacol 2007; 152:429-448.
60 Rabiet M, Huet E, Boulay F. The N-formyl peptide receptors and the anaphylatoxin C5a receptors: an overview. Biochimie 2007; 89:1089-1106.

61 Norgauer J, Dobos G, Kownatzki E, et al. Complement fragment $\mathrm{C} 3$ a stimulates $\mathrm{Ca}^{2+}$ influx in neutrophils via a pertussistoxin-sensitive G protein. Eur J Biochem 1993; 217:289-294.

62 Zwirner J, Gotze O, Moser A, et al. Blood- and skin-derived monocytes/macrophages respond to $\mathrm{C} 3$ a but not to $\mathrm{C} 3 \mathrm{a}$ (desArg) with a transient release of calcium via a pertussis toxin-sensitive signal transduction pathway. Eur J Immunol 1997; 27:2317-2322.

63 Vanek M, Hawkins LD, Gusovsky F. Coupling of the C5a receptor to $\mathrm{Gi}$ in $\mathrm{U}-937$ cells and in cells transfected with $\mathrm{C} 5 \mathrm{a}$ receptor cDNA. Mol Pharmacol 1994; 46:832-839.

64 Amatruda TT III, Gerard NP, Gerard C, Simon MI. Specific interactions of chemoattractant factor receptors with G-proteins. J Biol Chem 1993; 268:10139-10144.

65 Buhl AM, Avdi N, Worthen GS, Johnson GL. Mapping of the C5a receptor signal transduction network in human neutrophils. Proc Natl Acad Sci USA 1994; 91:9190-9194.

66 Gasque P, Singhrao SK, Neal JW, et al. The receptor for complement anaphylatoxin $\mathrm{C} 3 \mathrm{a}$ is expressed by myeloid cells and nonmyeloid cells in inflamed human central nervous system: analysis in multiple sclerosis and bacterial meningitis. J Immunol 1998; 160:3543-3554.

67 Ischenko A, Sayah S, Patte C, et al. Expression of a functional anaphylatoxin C3a receptor by astrocytes. J Neurochem 1998; 71:2487-2496.

68 Oksjoki R, Laine P, Helske S, et al. Receptors for the anaphylatoxins $\mathrm{C} 3 \mathrm{a}$ and $\mathrm{C} 5 \mathrm{a}$ are expressed in human atherosclerotic coronary plaques. Atherosclerosis 2007; 195:90-99.

69 Mizuno M, Blanchin S, Gasque P, Nishikawa K, Matsuo S. High levels of complement $\mathrm{C} 3 \mathrm{a}$ receptor in the glomeruli in lupus nephritis. Am J Kidney Dis 2007; 49:598-606.

70 Lee H, Whitfeld PL, Mackay CR. Receptors for complement C5a. The importance of C5aR and the enigmatic role of C5L2. Immunol Cell Biol 2008; 86:153-160.

71 Gutzmer R, Kother B, Zwirner J, et al. Human plasmacytoid dendritic cells express receptors for anaphylatoxins C3a and $\mathrm{C} 5 \mathrm{a}$ and are chemoattracted to $\mathrm{C} 3 \mathrm{a}$ and C5a. J Invest Dermatol 2006; 126:2422-2429.

72 Soruri A, Kim S, Kiafard Z, Zwirner J. Characterization of $\mathrm{C} 5 \mathrm{aR}$ expression on murine myeloid and lymphoid cells by the use of a novel monoclonal antibody. Immunol Lett 2003; 88:47-52.

73 Zwirner J, Fayyazi A, Gotze O. Expression of the anaphylatoxin C5a receptor in non-myeloid cells. Mol Immunol 1999; 36:877-884.

74 Ross GD, Medof ME. Membrane complement receptors specific for bound fragments of C3. Adv Immunol 1985; 37:217267.

75 van Lookeren Campagne M, Wiesmann C, Brown EJ. Macrophage complement receptors and pathogen clearance. Cell Microbiol 2007; 9:2095-2102.

76 Fearon DT. Identification of the membrane glycoprotein that is the $\mathrm{C} 3 \mathrm{~b}$ receptor of the human erythrocyte, polymorphonuclear leukocyte, B lymphocyte, and monocyte. J Exp Med 1980; 152:20-30.

77 Klickstein LB, Barbashov SF, Liu T, Jack RM, Nicholson- 
Weller A. Complement receptor type 1 (CR1, CD35) is a receptor for C1q. Immunity 1997; 7:345-355.

78 Ghiran I, Barbashov SF, Klickstein LB, et al. Complement receptor $1 / \mathrm{CD} 35$ is a receptor for mannan-binding lectin. $J$ Exp Med 2000; 192:1797-1808.

79 Krych-Goldberg M, Atkinson JP. Structure-function relationships of complement receptor type 1. Immunol Rev 2001; 180:112-122.

80 Bacle F, Haeffner-Cavaillon N, Laude M, Couturier C, Kazatchkine MD. Induction of IL-1 release through stimulation of the $\mathrm{C} 3 \mathrm{~b} / \mathrm{C} 4 \mathrm{~b}$ complement receptor type one $(\mathrm{CR} 1, \mathrm{CD} 35)$ on human monocytes. J Immunol 1990; 144:147-152.

81 Molina H, Kinoshita T, Webster CB, Holers VM. Analysis of $\mathrm{C} 3 \mathrm{~b} / \mathrm{C} 3 \mathrm{~d}$ binding sites and factor I cofactor regions within mouse complement receptors 1 and 2. J Immunol 1994; 153:789-795.

82 Ross GD. Regulation of the adhesion versus cytotoxic functions of the Mac-1/CR3/alphaMbeta2-integrin glycoprotein. Crit Rev Immunol 2000; 20:197-222.

83 Helmy KY, Katschke KJ Jr, Gorgani NN, et al. CRIg: a macrophage complement receptor required for phagocytosis of circulating pathogens. Cell 2006; 124:915-927.

84 Nussenzweig V, Bianco C, Dukor P, Eden A. Progress in Immunology. New York: Academic, 1971.

85 Pepys MB. Role of complement in induction of the allergic response. Nat New Biol 1972; 237:157-159.

86 Ochs HD, Wedgwood RJ, Heller SR, Beatty PG. Complement, membrane glycoproteins, and complement receptors: their role in regulation of the immune response. Clin Immunol Immunopathol 1986; 40:94-104.

87 O'Neil KM, Ochs HD, Heller SR, et al. Role of C3 in humoral immunity. Defective antibody production in C3-deficient dogs. J Immunol 1988; 140:1939-1945.

88 Papamichail M, Gutierrez C, Embling P, et al. Complement dependence of localisation of aggregated IgG in germinal centres. Scand J Immunol 1975; 4:343-347.

89 Carroll MC. The complement system in B cell regulation. Mol Immunol 2004; 41:141-146.

90 Carroll MC. Complement and humoral immunity. Vaccine 2008; 26 Suppl 8:I28-33.

91 Kinoshita T, Thyphronitis G, Tsokos GC, et al. Characterization of murine complement receptor type 2 and its immunological cross-reactivity with type 1 receptor. Int Immunol 1990; 2:651-659.

92 Fang Y, Xu C, Fu YX, Holers VM, Molina H. Expression of complement receptors 1 and 2 on follicular dendritic cells is necessary for the generation of a strong antigen-specific IgG response. J Immunol 1998; 160:5273-5279.

93 Carter RH and Fearon DT. CD19: lowering the threshold for antigen receptor stimulation of B lymphocytes. Science 1992; 256:105-107.

94 Dempsey PW, Allison ME, Akkaraju S, Goodnow CC, Fearon DT. C3d of complement as a molecular adjuvant: bridging innate and acquired immunity. Science 1996; 271:348-350.

95 Carsetti R, Kohler G, Lamers MC. Transitional B cells are the target of negative selection in the B cell compartment. $J$ Exp Med 1995; 181:2129-2140.

96 Fleming SD, Shea-Donohue T, Guthridge JM, et al. Mice deficient in complement receptors 1 and 2 lack a tissue injury- inducing subset of the natural antibody repertoire. J Immunol 2002; 169:2126-2133.

97 Reid RR, Woodcock S, Shimabukuro-Vornhagen A, et al. Functional activity of natural antibody is altered in Cr2-deficient mice. J Immunol 2002; 169:5433-5440.

98 Ahearn JM, Fischer MB, Croix D, et al. Disruption of the Cr2 locus results in a reduction in B-1a cells and in an impaired $\mathrm{B}$ cell response to T-dependent antigen. Immunity 1996; 4:251262.

99 Barrington RA, Zhang M, Zhong X, et al. CD21/CD19 coreceptor signaling promotes B cell survival during primary immune responses. J Immunol 2005; 175:2859-2867.

100Fischer MB, Goerg S, Shen L, et al. Dependence of germinal center B cells on expression of CD21/CD35 for survival. Science 1998; 280:582-585.

101 Cyster JG, Ansel KM, Reif K, et al. Follicular stromal cells and lymphocyte homing to follicles. Immunol Rev 2000; 176:181-193.

102Barrington RA, Pozdnyakova O, Zafari MR, Benjamin CD, Carroll MC. B lymphocyte memory: role of stromal cell complement and FcgammaRIIB receptors. J Exp Med 2002; 196:1189-1199.

103 Fischer W, Hugli T. Regulation of B cell functions by C3a and $\mathrm{C} 3 \mathrm{a}$ (desArg): suppression of TNF- $\alpha$, IL-6, and the polyclonal immune response. J Immunol 1997; 159:4279-4286.

104Morgan EL, Weigle WO, Hugli TE. Anaphylatoxin-mediated regulation of the immune response. I. C3a-mediated suppression of human and murine humoral immune responses. $J$ Exp Med 1982; 155:1412-1426.

105Morgan EL, Thoman ML, Weigle WO, Hugli TE. Anaphylatoxin-mediated regulation of the immune response. II. C5amediated enhancement of human humoral and T cell-mediated immune responses. J Immunol 1983; 130:1257-1261.

106Kupp LI, Kosco MH, Schenkein HA, Tew JG. Chemotaxis of germinal center B cells in response to C5a. Eur J Immunol 1991; 21:2697-2701.

107Ottonello L, Corcione A, Tortolina G, et al. rC5a directs the in vitro migration of human memory and naive tonsillar $\mathrm{B}$ lymphocytes: implications for B cell trafficking in secondary lymphoid tissues. J Immunol 1999; 162:6510-6517.

108Fearon DT, Carroll MC. Regulation of B lymphocyte responses to foreign and self-antigens by the CD19/CD21 complex. Annu Rev Immunol 2000; 18:393-422.

109Guinamard R, Okigaki M, Schlessinger J, Ravetch JV. Absence of marginal zone B cells in Pyk-2-deficient mice defines their role in the humoral response. Nat Immunol 2000; 1:31-36.

110 Pozdnyakova O, Guttormsen HK, Lalani FN, Carroll MC, Kasper DL. Impaired antibody response to group B streptococcal type III capsular polysaccharide in $\mathrm{C} 3$ - and complement receptor 2-deficient mice. J Immunol 2003; 170:84-90.

111 Molina H, Holers VM, Li B, et al. Markedly impaired humoral immune response in mice deficient in complement receptors 1 and 2. Proc Natl Acad Sci USA 1996; 93:3357-3361.

112 Da Costa XJ, Brockman MA, Alicot E, et al. Humoral response to herpes simplex virus is complement-dependent. Proc Natl Acad Sci USA 1999; 96:12708-12712.

113 Mehlhop E, Diamond MS. Protective immune responses against West Nile virus are primed by distinct complement activation pathways. $J$ Exp Med 2006; 203:1371-1381. 
114Haas KM, Hasegawa M, Steeber DA, et al. Complement receptors CD21/35 link innate and protective immunity during Streptococcus pneumoniae infection by regulating IgG3 antibody responses. Immunity 2002; 17:713-723.

115 Janeway CA Jr. Approaching the asymptote? Evolution and revolution in immunology. Cold Spring Harb Symp Quant Biol 1989; 54 Pt 1:1-13.

116 Gustavsson S, Kinoshita T, Heyman B. Antibodies to murine complement receptor 1 and 2 can inhibit the antibody response in vivo without inhibiting $\mathrm{T}$ helper cell induction. $J$ Immunol 1995; 154:6524-6528.

117 Kopf M, Abel B, Gallimore A, Carroll M, Bachmann MF. Complement component $\mathrm{C} 3$ promotes T-cell priming and lung migration to control acute influenza virus infection. Nat Med 2002; 8:373-378.

$118 \mathrm{Kim}$ AHJ, Dimitriou ID, Holland $\mathrm{MCH}$, et al. Complement $\mathrm{C} 5 \mathrm{a}$ receptor is essential for the optimal generation of antiviral CD8 ${ }^{+}$T cell responses. J Immunol 2004; 173:2524-2529.

119 Peng Q, Li K, Anderson K, et al. Local production and activation of complement up-regulates the allostimulatory function of dendritic cells through C3a-C3aR interaction. Blood 2008; 111:2452-2461.

120Fang C, Miwa T, Shen H, Song W. Complement-dependent enhancement of $\mathrm{CD}^{+} \mathrm{T}$ cell immunity to lymphocytic choriomeningitis virus infection in decay-accelerating factordeficient mice. J Immunol 2007; 179:3178-3186.

$121 \mathrm{Li} \mathrm{K}$, Anderson KJ, Peng Q, et al. Cyclic AMP plays a critical role in $\mathrm{C} 3 \mathrm{a}$-receptor-mediated regulation of dendritic cells in antigen uptake and T-cell stimulation. Blood 2008; 112:50845094.

122Liu J, Miwa T, Hilliard B, et al. The complement inhibitory protein DAF (CD55) suppresses $\mathrm{T}$ cell immunity in vivo. J Exp Med 2005; 201:567-577.

123 Heeger PS, Lalli PN, Lin F, et al. Decay-accelerating factor modulates induction of T cell immunity. J Exp Med 2005; 201:1523-1530.

124Liu J, Lin F, Strainic MG, et al. IFN- $\gamma$ and IL-17 production in experimental autoimmune encephalomyelitis depends on local APC-T cell complement production. J Immunol 2008; 180:5882-5889.

125 Strainic MG, Liu J, Huang D, et al. Locally produced complement fragments $\mathrm{C} 5 \mathrm{a}$ and $\mathrm{C} 3 \mathrm{a}$ provide both costimulatory and survival signals to naive $\mathrm{CD}^{+} \mathrm{T}$ cells. Immunity 2008; 28:425435.

126Lalli PN, Strainic MG, Yang M, Lin F, Medof ME, Heeger PS. Locally produced C5a binds to T cell-expressed C5aR to enhance effector T-cell expansion by limiting antigen-induced apoptosis. Blood 2008; 112:1759-1766.

127Zhou W, Patel H, Li K, Peng Q, Villiers MB, Sacks SH. Macrophages from $\mathrm{C} 3$-deficient mice have impaired potency to stimulate alloreactive T cells. Blood 2006; 107:2461-2469.

128 Martin U, Bock D, Arseniev L, et al. The human C3a receptor is expressed on neutrophils and monocytes, but not on B or T lymphocytes. J Exp Med 1997; 186:199-207.

129 Werfel T, Kirchhoff K, Wittmann M, et al. Activated human $\mathrm{T}$ lymphocytes express a functional $\mathrm{C} 3 \mathrm{a}$ receptor. $J$ Immunol 2000; 165:6599-6605.

130Zwirner J, Götze O, Begemann G, Kapp A, Kirchhoff K, Werfel T. Evaluation of $\mathrm{C} 3 \mathrm{a}$ receptor expression on human leuco- cytes by the use of novel monoclonal antibodies. Immunology 1999; 97:166-172.

131 Nataf S, Davoust N, Ames RS, Barnum SR. Human T cells express the $\mathrm{C} 5$ a receptor and are chemoattracted to C5a. J Immunol 1999; 162:4018-4023.

132Hopken UE, Lu B, Gerard NP, Gerard C. The C5a chemoattractant receptor mediates mucosal defence to infection. $\mathrm{Na}$ ture 1996; 383:86-89.

133Zhang X, Kimura Y, Fang C, et al. Regulation of Toll-like receptor-mediated inflammatory response by complement in vivo. Blood 2007; 110:228-236.

134Hawlisch H, Kohl J. Complement and Toll-like receptors: key regulators of adaptive immune responses. Mol Immunol 2006; 43:13-21.

135Iwasaki A, Medzhitov R. Toll-like receptor control of the adaptive immune responses. Nat Immunol 2004; 5:987-995.

136Cattaneo R. Four viruses, two bacteria, and one receptor: membrane cofactor protein (CD46) as pathogens' magnet. $J$ Virol 2004; 78:4385-4388.

137Karp CL, Wysocka M, Wahl LM, et al. Mechanism of suppression of cell-mediated immunity by measles virus. Science 1996; 273:228-231.

138Wagner C, Ochmann C, Schoels M, et al. The complement receptor 1, CR1 (CD35), mediates inhibitory signals in human T-lymphocytes. Mol Immunol 2006; 43:643-651.

139Capasso M, Durrant LG, Stacey M, Gordon S, Ramage J, Spendlove I. Costimulation via CD55 on human CD4 ${ }^{+} \mathrm{T}$ cells mediated by CD97. J Immunol 2006; 177:1070-1077.

140 Mold C. Role of complement in host defense against bacterial infection. Microbes Infect 1999; 1:633-638.

141 Ross SC, Densen P. Complement deficiency states and infection: epidemiology, pathogenesis and consequences of neisserial and other infections in an immune deficiency. Medicine (Baltimore) 1984; 63:243-273.

142Orren A, Potter PC, Cooper RC, du Toit E. Deficiency of the sixth component of complement and susceptibility to Neisseria meningitidis infections: studies in 10 families and five isolated cases. Immunology 1987; 62:249-253.

143 Summerfield JA, Sumiya M, Levin M, Turner MW. Association of mutations in mannose binding protein gene with childhood infection in consecutive hospital series. BMJ 1997; 314:1229-1232.

144Rooijakkers SH, van Strijp JA. Bacterial complement evasion. Mol Immunol 2007; 44:23-32.

145 Silverman GJ, Goodyear CS, Siegel DL. On the mechanism of staphylococcal protein A immunomodulation. Transfusion 2005; 45:274-280.

146Rooijakkers SH, Ruyken M, Roos A, et al. Immune evasion by a staphylococcal complement inhibitor that acts on $\mathrm{C} 3$ convertases. Nat Immunol 2005; 6:920-927.

147 Schmidtchen A, Holst E, Tapper H, Bjorck L. Elastase-producing Pseudomonas aeruginosa degrade plasma proteins and extracellular products of human skin and fibroblasts, and inhibit fibroblast growth. Microb Pathog 2003; 34:47-55.

148Joiner KA, Warren KA, Brown EJ, Swanson J, Frank MM. Studies on the mechanism of bacterial resistance to complement-mediated killing. IV. C5b-9 forms high molecular weight complexes with bacterial outer membrane constituents on serum-resistant but not on serum-sensitive Neisseria gonor- 
rhoeae. J Immunol 1983; 131:1443-1451.

149Joiner K, Brown E, Hammer C, Warren K, Frank M. Studies on the mechanism of bacterial resistance to complementmediated killing. III. C5b-9 deposits stably on rough and type 7 S. pneumoniae without causing bacterial killing. J Immunol 1983; 130:845-849.

150Pausa M, Pellis V, Cinco M, et al. Serum-resistant strains of Borrelia burgdorferi evade complement-mediated killing by expressing a CD59-like complement inhibitory molecule. $J$ Immunol 2003; 170:3214-3222.

151Horstmann RD, Sievertsen HJ, Knobloch J, Fischetti VA. Antiphagocytic activity of streptococcal $\mathrm{M}$ protein: selective binding of complement control protein factor H. Proc Natl Acad Sci USA 1988; 85:1657-1661.

152Ngampasutadol J, Ram S, Gulati S, et al. Human factor $\mathrm{H}$ interacts selectively with Neisseria gonorrhoeae and results in species-specific complement evasion. J Immunol 2008; 180:3426-3435.

153 Schneider MC, Prosser BE, Caesar JJ, et al. Neisseria meningitidis recruits factor $\mathrm{H}$ using protein mimicry of host carbohydrates. Nature 2009; 458:890-893.

154Lubinski J, Nagashunmugam T, Friedman HM. Viral interference with antibody and complement. Semin Cell Dev Biol 1998; 9:329-337.

155de Haas CJ, Veldkamp KE, Peschel A, et al. Chemotaxis inhibitory protein of Staphylococcus aureus, a bacterial antiinflammatory agent. J Exp Med 2004; 199:687-695.
156Postma B, Poppelier MJ, van Galen JC, et al. Chemotaxis inhibitory protein of Staphylococcus aureus binds specifically to the C5a and formylated peptide receptor. J Immunol 2004; 172:6994-7001.

157Dorig RE, Marcil A, Chopra A, Richardson CD. The human CD46 molecule is a receptor for measles virus (Edmonston strain). Cell 1993; 75:295-305.

158Lindahl G, Sjobring U, Johnsson E. Human complement regulators: a major target for pathogenic microorganisms. Curr Opin Immunol 2000; 12:44-51.

159Kallstrom H, Liszewski MK, Atkinson JP, Jonsson AB. Membrane cofactor protein (MCP or CD46) is a cellular pilus receptor for pathogenic Neisseria. Mol Microbiol 1997; 25:639647.

160Evans DJ, Almond JW. Cell receptors for picornaviruses as determinants of cell tropism and pathogenesis. Trends Microbiol 1998; 6:198-202.

161 Shafren DR, Dorahy DJ, Ingham RA, Burns GF, Barry RD. Coxsackievirus A21 binds to decay-accelerating factor but requires intercellular adhesion molecule 1 for cell entry. $J$ Virol 1997; 71:4736-4743.

162 Tanner J, Weis J, Fearon D, Whang Y, and Kieff E. EpsteinBarr virus gp350/220 binding to the B lymphocyte C3d receptor mediates adsorption, capping, and endocytosis. Cell 1987; 50:203-213.

163 Stoiber H, Clivio A, Dierich MP. Role of complement in HIV infection. Annu Rev Immunol 1997; 15:649-674. 